\title{
URGENSI PEMBENTUKAN KELEMBAGAAN BANK TANAH SEBAGAI ALTERNATIF PENYEDIAAN TANAH BAGI MASYARAKAT UNTUK KEPENTINGAN UMUM
}

\author{
Ranitya Ganindha \\ Universitas Brawijaya Malang \\ Jl. MT. Haryono 169 Malang \\ Email: r.ganindha@yahoo.co.id
}

Diterima: 10 Maret 2016 | Direview: 5 April 2016 | Disetujui: 5 Desember 2016

\begin{abstract}
Problems related to land will always be actual and complex issues. Population growth will not be accompanied by increments of shelter, economic progress, the need for all the infrastructure support for the space for humans, the level of public awareness and ease access to various parties on the ground. Land acquisition became the most complicated problems in the past few decades that are often faced by the government.It is stated that the state can only control the land and not as the owner of the land. In this study, the authors used the normative method with a comparative, historical and conceptual approach. The studies show the shifting meaning of land as one of the symbols of the economic concept of liberalism also play a role in the difficulty of gaining ground as a medium of development for the benefit of the public. Therefore there is a need of a method, and other strategies capable of addressing the land issues that are fundamental, effective, efficient sustainable. The land bank concept is very urgent to be applied in Indonesia. Land bank itself has a meaning as a private or government land reserve performed before starting development activities so as to avoid speculation in land prices. Land Bank is one means management of the resources necessary to improve the productivity of land use. The method uses market control and soil stabilization of local markets. Because that regulation is required as a legal umbrella for the implementation of the Bank's foundation soil and related institutional arrangements are authorized to implement the practice of the Land Bank
\end{abstract}

Key words: land banking, land provision, public interest

\begin{abstract}
Abstrak
Permasalahan terkait pertanahan akan selalu menjadi isu yang aktual dan bersifat kompleks. Pertumbuhan penduduk yang tidak akan diiringi dengan pertambahan tempat hunian, kemajuan ekonomi, kebutuhan akan segala infrastruktur penunjang bagi ruang gerak manusia, tingkat kesadaran hukum masyarakat dan kemudahan akses berbagai pihak terhadap tanah. Ketersediaan tanah untuk pembangunan menjadi permasalahan paling rumit dalam beberapa dasawarsa ini yang kerap dihadapi oleh pemerintah. UUPA telah mengamanatkan bahwa negara hanya boleh menguasai tanah dan bukan sebagai pemilik tanah. Dalam penelitian ini penulis menggunakan metode normatif dengan pendekatan historis, komparatif dan faktual. Pergeseran makna tanah sebagai salah satu simbol dari konsep ekonomi liberalisme juga berperan dalam sulitnya bagi pemerintah mendapatkan tanah sebagai media pembangunan untuk kepentingan umum. Berpijak dari permasalahan tersebut maka dibutuhkan suatu metode, dan strategi lain yang mampu mengatasi masalah pertanahan secara mendasar, efektif,efisien dan berkesinambungan. Berangkat dari permasalahan tersebut konsep bank tanah sangat mendesak untuk dapat
\end{abstract}


diterapkan di Indonesia sebagai salah satu alternatif penyediaan tanah bagi pembangunan untuk kepentingan umum. Bank tanah sendiri memiliki makna sebagai pencadangan tanah pemerintah ataupun swasta yang dilakukan sebelum kegiatan pembangunan dimulai sehingga menghindari spekulasi harga tanah. Bank Tanah adalah salah satu sarana manajemen sumber daya alam berupa tanah yang penting untuk meningkatkan produktivitas pemanfaatan tanah. Metode yang digunakan dalam bank tanah adalah kontrol pasar dan stabilisasi tanah pasar lokal. Karena itulah diperlukan regulasi sebagai payung hukum landasan pelaksanaan Bank tanah di Indonesia dan pengaturan terkait kelembagaan yang berwenang melaksanakan praktik Bank Tanah.

Kata kunci: bank tanah, penyediaan tanah, kepentingan umum

\section{Latar Belakang}

Salah satu permasalahan kompleks yang sering terjadi di bidang pertanahan Indonesia adalah penyediaan tanah untuk kebutuhan pembangunan terutama di perkotaan. ${ }^{1}$ Kelangkaan ini menyebabkan harga tanah di perkotaan terus naik dan taksiran harga tanah berdasarkan Nilai Jual Objek Pajak (NJOP) tidak berlaku. Penentuan harga tanah didasarkan kepada mekanisme harga pasar yang timbul dari persaingan tidak sempurna, sehingga pembebasan harga tanah untuk pembangunan memerlukan biaya yang sangat tinggi untuk pembayaran ganti rugi.

Intensitas kebutuhan pembangunan yang semakin meningkat serta kondisi makin terbatasnya ketersediaan tanah secara simultan berakibat pada semakin sulitnya optimalisasi pemanfaatan penggunaan tanah, khususnya bagi pelaksanaan pembangunan untuk kepentingan umum yang mengakibatkan terjadinya pertentangan kepentingan antar pihak atas sebidang tanah yang sama. Lahan atau tanah merupakan media yang sangat penting bagi suatu proses pembangunan untuk kepentingan umum utamanya yang membutuhkan tanah dalam jumlah yang sangat luas. Permasalahan yang paling sering terjadi adalah ketika pemerintah hendak memulai suatu pembangunan, lahan yang dikehendaki tidak atau belum tersedia. Akibat praktis yang ditimbulkan adalah pemerintah mengalami kesulitan dalam melakukan proses pembebasan lahan terutama terkait eksekusi pembebasan penguasaan lahan dan pembiayaannya yang menjadi sangat mahal. Kondisi tersebut mengakibatkan terjadinya proses pengadaan yang berlarut-larut. ${ }^{2}$

Pengadaan tanah yang berbelit kemudian menjadikan hak dari pihak lain yakni pemerintah ataupun swasta yang lebih membutuhkan dan mampu memanfaatkan bidang tanah tersebut dengan segera menjadi tidak terpenuhi sehingga potensi kesejahteraan yang akan didapat menjadi tidak dapat terwujud. Saat ini Pemerintah perlu melihat pembangunan infrastruktur yang paling dibutuhkan masyarakat, berkaitan dengan

1 Flecner L.H, Land Banking in the Control of Urban Development, (New York: Preger Publisher, 1974), hlm. 7.

2 Raffli Noor, "Manajemen Bank Tanah", Jurnal Direktorat dan Tata Ruang BAPPENAS Vol. I, (Maret 2014): 19. 
jaminan ketersediaan lahan pembangunan, terlebih dengan kebutuhan masyarakat akan lahan yang terus meningkat dengan bertambahnya penduduk. Pembentukan suatu lembaga yang menangani pengadaan tanah menjadi sangat penting untuk menghindari terjadi ketimpangan ketersediaan tanah dengan upaya Pemerintah melakukan pembangunan. ${ }^{3}$ Pasalnya, pengadaan tanah untuk kepentingan umum ini bertujuan untuk menyediakan tanah bagi pelaksanaan pembangunan guna meningkatkan kesejahteraan dan kemakmuran bangsa, negara, dan masyarakat dengan tetap menjamin kepentingan hukum pihak pemilik lahan yang memang berhak atas tanahnya.

Berdasarkan Pasal 6 Undang-undang Nomor 5 Tahun 1960 tentang Pokok-pokok Agraria bahwa setiap tanah memiliki fungsi sosial ${ }^{4}$ yang berarti kemanfaatan penggunaan tanah tersebut tidak hanya dapat dimiliki oleh pemilik hak atas tanah namun juga bagi masyarakat luas (kepentingan umum). Pengadaan tanah bagi pembangunan untuk kepentingan umum merupakan kegiatan menyediakan tanah dengan memberikan ganti rugi yang layak dan adil kepada yang berhak. ${ }^{5}$ Prinsip musyawarah menjadi landasan dalam pengadaan tanah menurut ketentuan Undang-undang nomor 2 tahun 2012 tentang
Pengadaan Tanah Bagi Pembangunan untuk Kepentingan Umum tersebut dan memiliki implikasi adanya keseimbangan kemanfaatan dalam penerapannya, sehingga dalam kegiatan pengadaan tanah tersebut pemilik tanah harus rela melepaskan tanahnya namun tidak boleh dirugikan. Pemilik lahan berhak atas penggantian ganti rugi yang layak sesuai yang telah diatur undang-undang. Akan tetapi, di dalam praktik kerap terjadi warga pemilik lahan merasa jumlah ganti kerugian tidak sepadang dengan nilai kerugian baik secara materiil maupun immateriil yang timbul akibat adanya pelepasan hak tersebut. Hal ini kerap menjadikan pelaksanaan kegiatan pembangunan yang disertai adanya pengadaan tanah akan berujung pada konflik berlarutlarut.

Permasalahan lain yang sering terjadi adalah penguasaan tanah oleh Badan Usaha Swasta (BUMS) dalam skala luas untuk dimanfaatkan di waktu yang akan datang. ${ }^{6}$ Pencadangan tanah seperti ini sebenarnya merupakan praktik spekulasi dan menurut peraturan perundangan termasuk dalam kategori penelantaran tanah. Praktik seperti itu banyak dilatarbelakangi faktor mencari keuntungan semata dengan mendapatkan perbedaan harga tanah saat dibeli dengan saat dijual kembali (dimanfaatkan) dalam

3 Basoeki Hadimoeljono, "Mencari Kelembagaan Pengendalian Pemanfaatan Ruang yang Efektif”, Jurnal Direktorat Tata Ruang dan Pertanahan BAPPENAS Vol. II, (Juni 2013): 23.

4 Pasal 18 UUPA berbunyi bahwa "Untuk kepentingan umum, termasuk kepentingan bangsa dan Negara serta kepentingan bersama dari rakyat, hak-hak tanah dapat dicabut dengan memberikan ganti kerugian yang layak dan menurut cara yang diatur undang-undang"

5 Pasal 1 ayat (2) Undang-undang Nomor 2 Tahun 2012 tentang Pengadaan Tanah Bagi Pembangunan untuk Kepentingan Umum.

6 Penyediaan Tanah untuk kawasan industri oleh pemerintah saat ini sekitar enam persen berbanding 94 persen 
masa waktu yang panjang hingga 10-20 tahun kemudian oleh pihak yang terlibat didalamnya.

Instrumen yang dapat digunakan oleh pemerintah saat ini untuk penyediaan tanah bagi pembangunan adalah melalui mekanisme land consolidation dan land readjusment. Konsolidasi tanah memiliki arti menata penggunaan lahan di perdesaan terkait areal pertanian atau kehutanan yang memiliki struktur kepemilikan yang terbagi-bagi guna meningkatkan produktivitas pertanian sedangkan Land Readjusment memiliki makna menata penggunaan lahan di perkotaan terutama pada kawasan dengan intensitas penggunaan lahan tinggi melalui reorganisasi lahan terbangun dan penyesuaian bidang tanah untuk meningkatkan kualitas pelayanan dan kehidupan masyarakat perkotaan.

Kedua instrumen tersebut diatur melalui Peraturan Kepala Badan Pertanahan Republik Indonesia dan Undang-undang tentang Rumah Susun, belum ada pengaturan tersendiri mengenai hal tersebut. Kekurangan dari kedua instrumen tersebut adalah penataan melalui pelepasan hak ataupun jual beli tanah baru dilakukan ketika kegiatan pembangunan akan dilaksanakan sehingga menyebabkan proses pengadaan tanah bisa saja berjalan tidak sesuai pada waktu yang direncanakan. Selain kedua instrumen tersebut, bank tanah dapat digunakan sebagai salah satu cara pengadaan tanah yang rendah konflik. Perbedaan konsep bank tanah dengan dua instrumen yang telah adalah bank tanah 'menyimpan' tanah sebelum kegiatan pembangunan dilaksanakan.

\section{Pembahasan}

Bank Tanah adalah salah satu sarana manajemen sumber daya yang penting untuk meningkatkan produktivitas pemanfaatan tanah. Metode yang diusung dalam bank tanah adalah kontrol pasar dan stabilisasi tanah pasar lokal. Bank tanah menjamin ketersediaan tanah untuk pelbagai keperluan pembangunan di masa yang akan datang, efisiensi APBN/ APBD, mengurangi konflik dalam proses pembebasan tanah dan mengurangi dampak buruk liberalisasi tanah. ${ }^{7}$

Manajemen bank tanah berhubungan dengan bagaimana perencanaan, pengorganisasian, pelaksanaan kegiatan serta pengawasan terhadap kegiatan bank tanah dalam mewujudkan tujuan bank tanah. Didukung oleh regulasi yang memadai dan kelembagaan yang kuat, manajemen bank tanah pada akhirnya bisa mewujudkan enam fungsi bank tanah, yaitu penghimpun tanah (land keeper); sebagai pengaman tanah (land warrantee); sebagai pengendali penguasaan tanah (land purchase); sebagai pengelola tanah (land management); sebagai penilaitanah (land appraisal); dan sebagai penyalur tanah (land distributor). Kegiatan bank tanah secara konseptual harus memuat kebijakan dan strategi optimalisasi pemanfaatan dan penggunaan tanah. ${ }^{8}$ Sumber-sumber tanah

yang disediakan oleh swasta.

7 Bernhard Limbong, Bank Tanah, (Jakarta: Margaretha Pustaka, 2013), hlm. 45.

8 Ibid. 
yang akan digunakan sebagai simpanan dalam bank tanah adalah tanah-tanah yang telah diklasifikasi dan diinventarisir oleh lembaga pertanahan yang berwenang/ BPN dan melekat hak atas tanah di dalamnya. Sumbersumber tanah tersebut diantaranya adalah tanah terlantar, tanah aset pemerintah, tanah erfacht, ${ }^{9}$ Tanah Absentee, ${ }^{10}$ Tanah fasilitas sosial atau tanah fasilitas umum, Tanah aset BUMN/ BUMD dan tanah sitaan. Mekanisme perubahan hak atas tanah tersebut sehingga menjadi aset pemerintah dilakukan melalui Akuisisi atau jual beli, tukar guling, hibah, pencabutan hak dan pembelian pada KPKNL.

Pembentukan bank tanah memerlukan koordinasi antar kementerian seperti Kementerian Agraria dan Tata Ruang serta Kementerian Pekerjaan Umum dan Perumahan Rakyat, lembaga inilah yang akan melakukan pembelian tanah sebelum proyek pembangunan infrastruktur dimulai. Sehingga dapat mengurangi makelar-makelar tanah yang melakukan pembelian tanah kemudian baru akan dijual apabila ada proyek pembangunan dengan harga tanah yang tinggi dan menguntungkannya. Selain itu diperlukan payung hukum yang dapat menjamin kepastian hukum pelaksanaan bank tanah ini.
Saat ini, Pemerintah terus melakukan pembahasan pembentukan Bank Tanah dalam bentuk Badan Layanan Umum (BLU) tersebut dengan Dewan Perwakilan Rakyat (DPR RI). ${ }^{11}$ Pembentukan bank tanah meliputi luas tanah yang dapat dibeli, mekanisme pengambilan tanah (seluruh atau bagian), cara perolehan asal tanah (dari mekanisme jual-beli atau tanah terlantar), mekanisme pendanaan (usulan mekanisme masuk kas keluar kas) dan apakah tanah yang telah dibeli akan dijual kembali atau hanya disewakan.

Di negara lain telah diterapkan dengan konsep yang hampir sama, yakni Korea, Jepang, Thailand, Taiwan, Amerika Serikat, Vietnam, Peru, Tunisia, Abu Dabi, Mumbai, Kolombia, dan Brasil. ${ }^{12}$ Di Korea, tepatnya Korea Selatan $84 \%$ penyesuaian kembali lahan (land readjustment) di masyarakat perkotaan. Di Jepang, setidaknya 1/3 dari keseluruhan lahan di perkotaan dikembangkan dengan land readjustment dengan faktor potensialnya yakni komunitas dan asosiasi masyarakat yang sangat beragam. Sementara di Taiwan, dalam satu dekade pertama seluas 2.100 Ha lahan di perkotaan ditata dengan land readjustment. ${ }^{13}$ Di Indonesia sendiri belum ada kelembagaan yang berfungsi untuk menjaga ketersediaan lahan, sehingga investor dan makelar-makelar

9 Tanah bekas erfacht verponding, atau tanah bekas perkebunan dapat saja dialihkan untuk kepemilikan pribadi tergantung kebijakan pemerintah daerah. Tanah bekas erfacht secara hukum menjadi tanah negara sejak Tahun 1980 atau 20 tahun setelah UUPA diterbitkan tahun 1960. Dengan telah menjadi tanah negara, kebijakan peruntukan berikutnya tergantung dari kebijakan pemerintah sebagai pihak yang mengurus negara.

10 Tanah Absentee adalah tanah pertanian yang dimiliki oleh perorangan ataupun keluarga yang berdomisili di luar kecamatan tanah tersebut berada. UUPA tidak mengizinkan pemilikan tanah secara absentee. Dalam waktu enam bulan tanah tersebut harus dikembalikan kepada orang yang berdomisili di kecamatan itu.

11 Ruslan Tambak, “Akhirnya Pemerintah Wacanakan Bank Tanah”, http://www.rmol.co/read/2015/02/13/191351/ Akhirnya-Pemerintah-Wacanakan-Bank-Tanah-, diakses 13 Pebruari 2015.

12 Badan Perencanaan Pembangunan Nasional Republik Indonesia (Bappenas), International Experiences in Land Banking and Related Landa Tools, email dengan narasumber dari Bappenas, diakses 13 Pebruari 2015.

13 Land Bank of Taiwan, “About Us", https://www.landbank.com/about, diakses 10 Pebruari 2015. 
tanah semakin leluasa melakukan penguasaan terhadap tanah.

Kendala yang akan dihadapi dalam pelaksanaan dan pengaturan kelembagaan bank tanah (land bank) adalah memerlukan jangka waktu yang panjang dan modal yang sangat besar, harus ada pengawasan kenaikan nilai, kebutuhan manajemen finansial dan pemberian kompensasi kepada pemilik tanah dengan adanya kegiatan pada awal, selama proyek dilakukan dan setelah dilakukannya suatu proyek.

Untuk mensukseskan pelaksanaan bank tanah, pemerintah dituntut untuk dapat memperkuat peran tata ruang sebagai ujung tombak pembangunan wilayah sesuai amanat. Pemerintah juga harus memperkuat lembaga pertanahan dan membenahi mutu administrasi pertanahan nasional khususnya terkait dengan pendaftaran tanah dan sertipikasi tanah. Pengaturan tata ruang yang pasti dan tegas juga diperlukan kepastian hukum terkait bukti kepemilikan dan penguasaan atas tanah. Lembaga pertanahan yang kuat dan berwibawa didukung penegakan hukum yang tegas dan konsisten pada akhirnya akan mencegah konflik pertanahan terkait tumpang tindih kepemilikan hak atas tanah yang selama ini kerap terjadi.

Mekanisme penyediaan tanah melalui Bank Tanah menjadi mendesak untuk dilaksanakan untuk menghindari peningkatan harga tanah yang terlalu tinggi terutama di daerah perkotaan. Bank Tanah dapat dijadikan salah satu alternatif Penyediaan Tanah di samping mekanisme pengadaan tanah yang telah diatur oleh Undang-undang No. 2 Tahun 2012. Konsep Bank Tanah memiliki kemiripan konsep dengan Bank Konvensional pada umumnya. Kedua bentuk Bank ini memiliki fungsi intermediasi di mana pada Bank Tanah yang dihimpun dan disalurkan adalah tanah alih-alih uang. Masyarakat melalui mekanisme Bank Tanah dapat membantu Pemerintah dengan menghimpunkan tanahnya di Bank Tanah dan akan disalurkan dalam bentuk hak-hak lain semisal sewa dan sebagainya, masyarakat akan mendapatkan keuntungan ekonomis darinya.

Tujuan yang hendak dicapai dalam penulisan jurnal ini adalah sebagai berikut Untuk mengetahui dan menganalisis payung hukum dan pelembagaan bank tanah untuk mendukung program pembangunan yang dilaksanakan Pemerintah terhadap ketersediaan lahan di Indonesia, untuk mengetahui dan menemukan model / bentuk bank tanah yang tepat khususnya di daerah urban yang memiliki harga tanah yang sangat tinggi.

Metodologi Penelitian ini menggunakan jenis penelitian normatif. Yakni dengan melakukan penelitian yang mengkaji hukum, menelaah isu hukum yang dikaitkan dengan undang-undang ataupun regulasi. Serta untuk mengkaji syarat-syarat normatif dari hukum sudah terpenuhi atau belum dengan ketentuan dan bangunan hukum itu sendiri. ${ }^{14}$ 
Penulisan ini berusaha menganalisis peraturan perundang-undangan yang berkaitan dengan telaah mengenai payung hukum pembentukan bank tanah di Indonesia, sehingga dapat dihasilkan suatu temuan hukum untuk dijadikan rujukan atau telaah hukum bagi Pemerintah, khususnya legislator dalam membuat peraturan perundang-undangan. Dengan demikian, maka pendekatan yang dilakukan dalam penelitian ini yakni pendekatan perundang-undangan (statute approach), perbandingan hukum (comparative approach) dan pendekatan konsep (conseptual approach).

\section{A. Urgensi Pembentukan Kelemba- gaan Bank Tanah}

\section{Kebutuhan tanah untuk pemba- ngunan}

Salah satu target Rencana Pembangunan Jangka Panjang Nasional tahun 2005-2025 $5^{15}$ yang ingin dicapai adalah pembangunan infrastruktur untuk mencapai kondisi layanan negara yang optimal. Indeks daya saing global Indonesia ditinjau dari aspek daya saing infrastruktur berada di peringkat 72 pada tahun 2014-2015, masih tertinggal dibanding negara Malaysia yang berada di peringkat 20. Gambaran umum terkait kondisi infrastruktur negara saat ini adalah kondisi jalan khususnya jalan daerah yang kurang memadai, Pembangunan sarana transportasi kereta api sebagai sarana transportasi massal yang kurang memadai, peningkatan efektivitas serta efisiensi pembiayaan dalam Penyediaan Infrastruktur.

Intensitas kebutuhan pembangunan yang semakin meningkat serta kondisi makin terbatasnya ketersediaan tanah secara simultan berakibat pada semakin sulitnya optimalisasi pemanfaatan penggunaan tanah, khususnya bagi pelaksanaan pembangunan untuk kepentingan umum, sehingga yang terjadi kemudian adalah pertentangan kepentingan antar pihak atas sebidang tanah yang sama.

Perkembangan terkini yang terjadi kemudian adalah penguasaan tanah oleh badan usaha swasta dalam skala luas untuk dimanfaatkan jauh di waktu yang akan datang. Pencadangan tanah seperti ini sebenarnya merupakan praktik spekulasi dan menurut peraturan perundangan termasuk dalam kategori penelantaran tanah. Praktik seperti itu banyak dilatarbelakangi faktor mencari keuntungan semata dengan mendapatkan perbedaan harga tanah saat dibeli dengan saat dijual kembali (dimanfaatkan) dalam masa waktu yang panjang hingga 10-20 tahun kemudian oleh pihak yang terlibat didalamnya. Badan usaha swasta yang bergerak di bidang properti dengan status kepemilikan tanah berupa Hak Guna Bangunan (HGB), dan di bidang perkebunan dengan status kepemilikian tanah berupa Hak Guna Usaha (HGU), serta sebagai badan usaha swasta yang bergerak dalam penyiapan tanah untuk kawasan perindustrian dengan 
regulasi Lingkungan Siap Bangun (Lisiba) dan Kawasan Siap Bangun (Kasiba) teridentifikasi yang paling sering melakukan praktik seperti ini. Dengan demikian dapat dikatakan bahwa penguasaan tanah dalam skala luas tadi tidak diusahakan untuk mendorong pembangunan ekonomi tetapi cenderung dimanfaatkan sebagai objek spekulasi dan investasi oleh beberapa pihak tertentu. Lebih dari itu, luasan tanah yang terindikasi diterlantarkan tersebut telah menjadi agunan serta dibebankan haknya melalui hak tanggungan di lembaga keuangan/perbankan.

Beberapa proyek infrastruktur pemerintah yang terhambat proses pengadaan tanah diantaranya adalah proyek pembangkit Listrik Tenaga Uap (PLTU) 2 x 1000 MW di Jawa Tengah di Batang Jawa Tengah yang membutuhkan tanah seluas 200 ha dan tanah yang belum dibebaskan adalah 29 ha, Jalur Kereta Sulawesi yang hingga saat ini tingkat ketersediaan lahan masih 0 persen, Proses Pembangunan Gorontalo Ring Road yang juga terkendala dalam hal pembebasan lahan, Proyek pembangunan Jalan Tol Akses Pelabuhan Tanjung Priok sepanjang $11,4 \mathrm{Km}$ dalam rangka debottlenecking kemacetan di pintu pelabuhan dan jalan di sekitar Tanjung Priok, Pembangunan Waduk Jatigede, Pembangunan Jalan Tol Cibitung dan Cilincing. ${ }^{16}$

Pembangunan infrastruktur tersebut tentu saja membutuhkan biaya yang tidak sedikit. Skema yang akan digunakan adalah skema pembiayaan APBN, APBD dan berbagai kebijakan melalui pendekatan institusional. Bank Khusus pengadaan tanah untuk pembangunan infrastruktur (Bank Tanah) merupakan salah satu kebijakan yang akan digunakan untuk memenuhi ketersediaan tanah penunjang pembangunan.

Bank tanah diharapkan dapat mengatasi berbagai hambatan penyediaan tanah terkait pembangunan infrastruktur yaitu mengatasi proses pengadaan lahan yang kaku, keterbatasan kompetensi dan jumlah aparat bidang pertanahan di tingkat pusat dan daerah, Harga lahan yang semakin tinggi namun terdapat keterbatasan dana pemerintah, sebagai instrumen pengadaan tanah yang cepat dan efektif di Indonesia.

Permasalahan yang dihadapi dalam pembangunan untuk kepentingan umum adalah ketersediaan tanah untuk pembangunan terutama pembangunan sarana prasaran fisik seperti jalan, jembatan, pelabuhan, bendungan dan lain sebagainya yang membutuhkan tanah. Pemerintah mengalami kesulitan dalam penyediaan tanah dikarenakan adanya penolakan dari masyarakat yang enggan melepaskan tanahnya karena besaran ganti rugi yang tidak sesuai. Selain itu keberadaan spekulan tanah juga menghambat penyediaan tanah karena harga tanah menjadi melambung 
dan tidak terkendali yang mengakibatkan biaya pembebasan lahan menjadi besar.

\section{Tujuan pembentukan bank tanah untuk pembangunan}

Tujuan umum pembentukan Bank Tanah adalah untuk menyediakan lahan untuk pembangunan kepentingan umum sehingga rencana pembangunan oleh pemerintah dan swasta tidak terhambat. Selain itu tujuan Bank Tanah dari segi pemerintahan adalah untuk (i) membentuk pertumbuhan regional masyarakat; (ii) menata perkembangan kota; (iii) Mengurangi spekulasi tanah; (iv) Menurunkan biaya perbaikan oleh masyarakat; dan (v) Menurunkan biaya pelayanan publik akibat pola pembangunan. ${ }^{17}$

\subsection{Manajemen bank tanah}

Akuisisi tanah publik yang dilakukan bank tanah diadakan untuk penggunaan masa depan dan dalam rangka menerapkan kebijakan tanah publik. ${ }^{18}$ Bank tanah mengacu pada proses akuisisi tanah masyarakat yang belum dikembangkan atau tidak produktif untuk tujuan pengembangan di masa mendatang. ${ }^{19}$ Efektifitas penerapan konsep bank tanah sangat tergantung pada regulasi yang mengaturnya, kelembagaan, dukungan pendanaan, dan bagaimana kegiatan bank tanah itu dikelola berdasarkan prinsip-prinsip manajemen modern.
Manajemen bank tanah berhubungan dengan bagaimana perencanaan, pengorganisasian, pelaksanaan kegiatan serta pengawasan terhadap kegiatan bank tanah dalam mewujudkan tujuan bank tanah. Didukung oleh regulasi yang memadai dan kelembagaan yang kuat, manajemen bank tanah pada akhirnya bisa mewujudkan enam fungsi bank tanah, yaitu penghimpun tanah (land keeper); sebagai pengaman tanah (land warrantee); sebagai pengendali penguasaan tanah (land purchase); sebagai pengelola tanah (land management); sebagai penilai tanah (land appraisal); dan sebagai penyalur tanah (land distributor). Kegiatan bank tanah secara konseptual harus memuat kebijakan dan strategi optimalisasi pemanfaatan dan penggunaan tanah.

Khusus untuk bank tanah pemerintah, kelembagaan bangk tanah dapat mengambil beberapa bentuk, yaitu: (1) bank tanah BUMN, (2) bank tanah departemen atau lembaga, (3) bank tanah BPN, (4) bank tanah BPN, (4) bank tanah pemerintah daerah, (5) bank tanah pemerintah kota, (6) bank tanah BUMD. Bentuk lembaga bank tanah yang paling ideal dikembangkan di Indonesia adalah bank tanah BUMN. Pembentukan lembaga bank tanah berupa BUMN telah dilaksanakan di sejumlah Negara seperti Singapura dan Jepang.

Keberhasilan pelaksanaan bank tanah

17 Ibid., hlm. 34.

18 Van Dijk, T. and D Kopeva, "Land Banking And Central Europe: Future Relevance Current Initiatives, Western European Past Experience", Journal Land Use Policy Vol. 30, (April 2003): 150.

19 Frank S. Alexander, "Land Banking As Metropolitan Policy”, Washington Brookings Intitution Metropolitan, https://www.brookings.edu/research/land-banking-as-metropolitan-policy/, diakses 12 Januari 2016. 
mensyaratkan dukungan dari berbagai faktor, antara lain:(1) Political Will sekaligus Political Action dari pemerintah, (2) rencana tata ruang wilayah yang tuntas, (3) Tertib administrasi pertanahan, (4) sumber daya manusia dan supporting system yang memadai, dan partisipasi masyarakat yang aktif. ${ }^{20}$

Permasalahan penyediaan tanah bagi pembangungan yang terjadi di Indonesia adalah Pengadaan Tanah bagi Pembangunan Untuk Kepentingan Umum telah menyelesaikan kepastian masalah lamanya waktu yang dibutuhkan karena UU tersebut sudah menentuka kerangka waktu pada tahapan dalam pengadaan tanah masing-masing proyek infrastruktur secara pasif, namun UU No. 2 tahun 2012 belum dapat mengakomodasi kebutuhan pengadaan tanah dalam wilayah/ skala besar (nasional) sehingga dibutuhkan instrumen pengadaan tanah yang aktif, peraturan perundangan yang terkait dengan pertanahan masih belum memiliki peraturan pelaksanaan rinci yaitu format-format detail persiapan dan pelaksanaan pada implementasi pada Perpres No. 71 Tahun 2014, belum tersedia instrumen pengadaan tanah selain Konsolidasi tanah/ Land Readjusment untuk Indonesia, dan Terbatasnya ketersediaan tanah dan tingginya nilai tanah terutama di wilayah perkotaan.

Dari uraian permasalahan yang telah dikemukakan dan kompleksitas permasalahan terkait pertanahan, pembentukan Bank Tanah memiliki urgensi atau tingkat kebutuhan yang mendesak. Merunut pada landasan konstitusional yang telah diatur dalam UUD Negara Republik Indonesia pada pasal 33 ayat (3) yakni memiliki visi bertujuan untuk mensejahterakan kehidupan bangsa. Penjabaran lebih lanjut dari ketentuan pasal 33 UUD 1945 tersebut telah ditegaskan secara jelas dalam pasal 2 ayat (2) UUPA tahun 1960, bahwa negara berwenang:

Mengatur dan menyelenggarakan peruntukan, penggunaan, persediaan tanah, atau pemeliharanya.

Menentukan dan mengatur hak-hak yang dapat dipunyai atau (bagian dari) bumi, air, dan ruang angkasa itu.

Menentukan dan mengatur hubunganhubungan hukum antara orang-orang dan perbuatan-perbuatan hukum yang mengenai bumi, air, dan ruang angkasa, segala sesauatunya dengan tujuan untuk mencapai sebesar-besarnya kemakmuran rakyat dalam masyarakat adil dan makmur.

Keberadaan Bank Tanah dapat menjalankan apa yang telah diamanatkan oleh UUD NRI Tahun 1945 dan UUPA 1960 tersebut. Bank tanah dapat dijadikan sebagai instrumen untuk mendukung pelaksanaan berbagai kebijakan pertanahan dan mendukung tercapainya pembangunan melalui pengembangan wilayah, pengadaan tanah secara adil.

Secara konseptual, bank tanah siap bangun, baik secara fisik maupun secara administratif, yaitu tanah yang akan dijual

20 Land Bank of Philippines, “About History”, https://www.landbank.com/history, diakses 20 September 2015. 
telah dilengkapi dengan sertifikat hak atas tanah; tersedianya tanah untuk berbagai keperluan; terkendalinya harga tanah serta memberantas spekulasi tanah; dan mendukung pembangunan yang berkelanjutan melalui administrasi pengelolaan pertanahan (penataan ruang dan penatagunaan tanah). ${ }^{21}$

Dalam tataran empiris, Bank Tanah dapat menjawab berbagai persoalan mendesak yang selama ini kerap membayangi pembangunan infrastruktur seperti keterbatasan stok tanah yang dapat digunakan untuk pembangunan, melakukan penghematan terhadap dana APBN dan APBD, mengurangi konflik yang kerap terjadi dalam pembebasan tanah dan mengurangi dampak buruk dari praktik spekulasi harga tanah yang kerap dilakukan oleh mafia tanah.

Dalam operasionalisasinya, bank tanah haruslah menjadi instrumen pelaksana UU No. 2 Tahun 2012 tentang Pengadaan Tanah bagi Kepentingan Umum dan hanya dikhususkan untuk pengadaan tanah bagi Kepentingan Umum. Peraturan Presiden tentang Badan Layanan Umum pelaksana Bank Tanah menjadi aturan pelaksana dari undang-undang tersebut dan hal yang harus dilakukan adalah amandemen (perubahan) terhadap UU No. 2 Tahun 2012 sebagai payung hukum landasaan pelaksanaan Bank Tanah.

\subsection{Kelembagaan bank tanah dan mekanisme pelaksanaan di Indonesia}

\footnotetext{
21 Bernhard Limbong, op.cit., 2013, hlm. 213.
}

Dalam tataran pelaksanaan, konsep kelembagaan Bank Tanah haruslah disandarkan kepada UUD NRI Tahun 1945 dan UUPA Tahun 1960. Bank tanah haruslah diselenggarakan oleh lembaga yang berbadan hukum publik baik sebagai unit dan departemen maupun berbentuk BUMN. Seperti yang telah diutarakan sebelumnya, tanah memegang peranan yang amat sentral, oleh karena itulah pemerintah harus turut andil dalam segala kegiatan pelaksanaannya.

Bank tanah pada dasarnya tidak berbeda jauh dengan Bank Konvensional, kedua lembaga ini memiliki kesamaan fungsi intermediasi yaitu sebagai penghimpun dan penyalur dana masyarakat. Apabila Bank Konvensional menghimpun dana dari masyarakat dalam wujud tabungan simpanan dan giro, pada Bank Tanah yang dihimpun adalah tanah terlantar. Dalam Bank Konvensional dana disalurkan dalam bentuk Pinjaman (kredit) sedangkan Bank tanah menyalurkan tanah kepada masyarakat untuk kepentingan umum, untuk lebih jelas perbedaan Bank Tanah dan Bank Konvensional dapat dilihat dalam Tabel 1.

\subsection{Ide tentang pembentukan bank tanah}

Sejarah penyediaan tanah di Indonesia melalui praktik-praktik penyediaan dan penjualan tanah kepada masyarakat telah dimulai sejak zaman Belanda yang waktu itu dikenal melalui lembaga Grond Bedrift di beberapa Gementee di Jawa, seperti 
Tabel 1. Perbedaan Bank Tanah dan Bank Konvensional

\begin{tabular}{|l|l|}
\hline \multicolumn{1}{|c|}{ PERSAMAAN } & \multicolumn{1}{c|}{ PERBEDAAN } \\
\hline $\begin{array}{l}\text { Dari segi fungsinya, keduanya dapat } \\
\text { menyimpan aset; membantu stabilisasi pasar } \\
\text { sekunder; memegang cabang modal. }\end{array}$ & $\begin{array}{l}\text { Bank tanah khusus untuk menyimpan } \\
\text { sekaligus mengelola tanah. } \\
\text { Bank konvensional: menyimpan sekaligus } \\
\text { mengelola uang dan benda berharga serta } \\
\text { surat berharga lainnya. }\end{array}$ \\
\hline $\begin{array}{l}\text { dari segi pelaksanaannya, keduanya dapat } \\
\text { dijalankan, baik oleh pemerintah maupun } \\
\text { swasta. }\end{array}$ & $\begin{array}{l}\text { Bank konvensional fokus pada pasar nasional } \\
\text { dan internasional. Bank tanah fokus pada } \\
\text { stabilisasi lingkungan dan masyarakatserta } \\
\text { perencanaan penggunaan tanah. }\end{array}$ \\
\hline $\begin{array}{l}\text { Dari segi operasionalisasinya, keduanya } \\
\text { beroperasi dalam kerangka regulasi }\end{array}$ & $\begin{array}{l}\text { Bank konvensional lebih profit oriented. } \\
\text { Bank tanah; prioritasnya, nirlaba meskipun } \\
\text { ada juga yang profit oriented terutama yang } \\
\text { dikelola oleh swasta. }\end{array}$ \\
\hline
\end{tabular}

Sumber: Bernhard Limbong, 2013

Batavia Semarang, dan Surabaya. Dalam periode kemerdekaan, berkembang menjadi perusahaan Tanah dan Bangunan. ${ }^{22}$

Beberapa contoh dapat dideskripsikan sebagai berikut. Untuk mengatasi kesulitan penyediaan tanah bagu keperluan pembangunan perumahan para pegawai, pemerintah Daerah DKI membuat perusahaan Tanah dan Bangunan. Perusahanan tanah dan bangunan mengadakan/mengumpulkan tanah, kemudian mematangkan tanah tersebut dengan membangun prasarana jalan dan membagi bagi menjadi kapling kapling yang siap untuk mendirikan bagungan.Secara bertahap kaling ini dijual dengan harga di bawah harga pasar kepada pegawai/karyawan. Bentuk usaha yang demikian (yaitu belum mura-matangkan-simpan dan jual) merupakan bentuk Land banking dan telah memberikan keuntungan (disubsidi dengan mudah) dan manfaat kemudahan dalam penyediaan tanah untuk pembangunan. ${ }^{23}$

Dalam rangka penyediaan tanah untuk industri, pemerintah telah mendirikan perusahaan untuk mengelola kawasan industri (indrustrial estate) seperti Jakarta Industrial Estate Pulo Gadung (JIEP) di Jakarta dan Surabaya industrial estate Rungkut (SIER) di Surabaya. Perusahaan ini melakukan embelian dan pengadaan tanah mentah untuk dimatankan kemudian dijual kembaliguna pembangunan pabrik / industri. Untuk lebih memicu tumbuhnya industri, dengan Keppres No. 53 tahun 1989 tentang Kawasan Industri, dimungkinkan pihak swasta dapat mengeola kawasan industri. Adapun dengan dikeluarkannya Undang-undang No. 4 Tahun

22 Hilman Tisnawan, Optimalisasi Pemberdayaan Kekayaan Negara, (Jakarta: FHUI, 2005), hlm. 106.

23 Ibid., hlm. 80. 
1992 tentang Perumahan dan Permukiman, antara lain memuat ketentuan bahwa pembangunan perumahan dan prmukiman dikembangkan melalui awasan siab bangun (KSB), pada hakikatnya merupakan kegiatan bank tanah pula. ${ }^{24}$

Praktik semacam bank tanah ini telah dilakukan pula dalam rangka pelaksanaan konsolidasi tanah (land consolidation). Melalui konsolidasi tanah dapay disediakan tanah untuk pembangunan jalan dan prasarana lainnya tanpa memberikan kompensasi kepada pemilik tanah. Di samping itu, untuk membantu pegawai golongan rendahmenengah diadakan pembelian tanah mentah (tanah tanpa prasarana jalan) dengan harga murah, kemudian dimatangkan melalui konsolidasi tanah dan dijual murah kepada pegawai yang dikenal dengan pola subsidi silang dalam rangka program penyediaan rumah murah oleh pemerintah.

\section{Konsep pembentukan lembaga bank tanah}

Memperhatikan ketentuan Pasal 9, ayat (3), dan Pasal 15, ayat (i) PP No. 11 Tahun 2010 tentang Penertiban dan Pendayagunaan Tanah Terlantar terlihat bahwa negara memiliki kewenangan untuk melakukan pencadangan tanah. Berbeda dengan badan usaha swasta, negara dalam melakukan pencadangan tanah tidak terikat waktu untuk melakukan pemanfaatan pada bidang-bidang tanah yang dikuasai karena pada akhirnya, setiap bidang tanah yang dikuasai negara akan digunakan sebesar-besarnya untuk kemakmuran rakyat sebagaimana tercantum dalam Pasal 33, UUD 1945.

Praktik pencadangan tanah secara umum dikenal dengan terminologi "Bank Tanah", dan di Indonesia secara luas dilakukan baik oleh badan usaha swasta, maupun BUMD, dan BUMN. Entitas badan hukum yang mewakili negara secara khusus untuk melakukan pencadangan tanah, atau Bank Tanah itu sendiri justru belum dimiliki oleh Negara Indonesia.

Terkait dengan telah terbitnya UU No. 2 Tahun 2012 tentang Pengadaan Tanah bagi Pembangunan untuk Kepentingan Umum, dimana negara diberi kewenangan untuk melepaskan hak penduduk atas bidang tanah yang diperlukan untuk pembangunan bagi kepentingan umum, dengan syarat kesesuaian dengan rencana tata ruang wilayah, sebenarnya sudah saatnya Indonesia memiliki institusi Bank Tanah yang merupakan badan hukum yang mewakili negara dalam melakukan pencadangan tanah bagi keperluan negara.

Pada praktiknya Bank Tanah harus bisa menjadi instrumen utama dalam mencegah terjadinya spekulasi harga tanah, dimana perlu ditetapkan bahwa secara falsafah Bank Tanah tidak diperbolehkan mendapat untung dari selisih harga penjualan tanah yang 
dimilikinya.Untuk itu secara logis, dalam teknis pengelolaannya terdapat dua opsi, yaitu: ${ }^{25}$

a. Tidak mengambil selisih harga, dalam arti menjual bidang tanah terkait sesuai dengan harga ketika dibeli.

b. Pada opsi ini seluruh biaya operasional organisasi Bank Tanah dibiayai melalui APBN.

Menetapkan selisih harga tertentu; Pada opsi ini, keuntungan dibatasi maksimal 5\% dan harus digunakan sepenuhnya untuk membiayai kebutuhan operasional organisasi Bank Tanah.

Dengan demikian diharapkan, selain keadilan sosial dapat diwujudkan penyediaan tanah untuk pembangunan bagi kepentingan umum juga dapat lebih terjamin dengan tetap mengacu pada prinsip-prinsip keadilan bagi seluruh rakyat Indonesia. Selain itu juga terlihat jelas bahwa praktik pencadangan tanah atau lebih dikenal dengan Bank Tanah, hanya boleh dilakukan oleh organisasi badan hukum yang mewakili negara dan tidak dapat atau tidak boleh dilakukan oleh badan hukum swasta (atau pun badan usaha swasta).

\section{Mekanisme kegiatan bank tanah}

Dalam memperoleh tanah, bank tanah melakukan beberapa tahapan kegiatan, yakni: tahap penyediaan, pematangan dan tahap pendistribusian tanah. ${ }^{26}$

1. Penyediaan tanah

Umumnya, bank tanah dapat menyediakan tanah dengan cara akuisisi (pengadaan tanah), mekanisme jual-beli, dan tukar-menukar. Beerapa kegiatan penting dalam tahapan penyediaan ini antara lain perencanaan, survey fisik tanah, verifikasi status tanah, rencana alokasi biaya pembelian/pengadaan tanah. Kegiatan lain yang tak kalah penting ialah usaha mengetahui sejarah tanah sehingga kelak bisa terhindar dari sengketa kepemilikan atau penguasaan tanah.

2. Pematangan tanah

Pada tahap ini bank tanah menyiapkan sarana dan prasarana atau fasilitas pendukung antara lain pembangunan infrastruktur, saluran sanitasi, fasilitas umum dan layanan publik dan sebagainya. Khusus bank tanah swasta, kegiatan pematangan tanah ini mengarah pada pembangunan infrastruktur inti dan penunjang berdasarkan kalkulasi ekonomi dan tata kelola yang cermat agar investasi tanah tidak mengalami kerugian. Kegiatan ini harus memperhatikan dan mengacu pada rencana tata ruang wilayah yang telah ditetapkan oleh pemerintah.

Tahapan pematangan tanah sangat krusial karena menentukan nilai tanah dan daya tarik masyarakat atau investor untuk membeli atau menyewa lahan. Nilai ekonomis tanah sangat penting dalam proses pematangan tanah ini. Nilai ekonomis tanah banyak ditemukan oleh faktor status kepemilikan tanah, kemudahan, kemanfaatan, fasilitas, dan kelembagaan.

3. Pendistribusian tanah

Sebelum dilakukan pendistribusian

25 World Bank, "International Experience in Land Banking and Related Tool", http://elibrary.worldbank.org/ page/wb-books, diakses 24 Januari 2016.

26 Bernhard Limbong, op.cit., 2013, hlm. 90. 
tentunya harus didahului dengan kesiapan data antara lain mengenai berapa luas tanah yang menjadi obyek bank tanah, bidang tanah mana yang menjadi prioritas (umum atau khusus) dan berapa lama waktu yan dibutuhkan untuk pematangan sebelum didistribusikan. Tahapan

Tabel 2. Mekanisme Kegiatan Bank Tanah berikutnya, menentukan untuk apa atau untuk siapa tanah didistribusikan, berapa persen dari jumlah tanah yang tersedia yang dapat di distribusikan dan bagaimana pendistribusian tanahnya.

Apabila digambarkan dalam bentuk tabel maka mekanisme kerja Bank Tanah dapat digambarkan dalam Tabel 2.

\begin{tabular}{|l|l|l|}
\hline \multicolumn{1}{|c|}{ Penyediaan Tanah } & \multicolumn{1}{|c|}{ Pematangan Tanah } & \multicolumn{1}{c|}{ Pendistribusian Tanah } \\
\hline - pengadaan Tanah & - pembuatan jalan & - luas tanah objek bank \\
- pencabutan Hak atas Tanah & • pembangunan jaringan & bagian tanah yang mau \\
- mekanisme jual-beli & listrik, telepon & didistribuskan yang \\
- tukar-menukar & - penyediaan iar bersih, & tersedia (umum atau \\
- pemanfaatan tanah & sanitasi & khusus) \\
terlantar & - pembangunan akses & tujuan dan targt \\
- administrasi pertanahan; & untuk layanan dasar & pendistribusian \\
biaya perizinan, pajak, & seperti sarana pendidikan, & cara pendistribusian \\
biaya overhead lainnya. & kesehatan dan perumahan & - administrasi perizinan; \\
& administrasi pertanahan; & biaya perizinan, pajak, \\
& biaya perizinan, pajak, & biaya overhead lainnya. \\
\hline
\end{tabular}

Sumber: Bernhard Limbong, 2013

B. Kelembagaan Bank Tanah sebagai Solusi Penyediaan Tanah bagi Pembangunan

Pemerintah memerlukan keberadaan Bank Tanah sebagai penjaga suplai kebutuhan pemerintah akan tanah terutama di kota besar. Tanah juga harus memberikan manfaat kepada masyarakat golongan ekonomi bawah tanpa terkecuali. Bank Tanah dapat digunakan sebagai wadah untuk mengatur distribusi tanah yang ditujukan sebagai kegiatan pembangunan. Melalui mekanisme Bank tanah ini juga pemerintah dapat menahan praktik spekulasi tanah dan menjaga kuota distribusi tanah bagi pengembang. Hal ini penting dilakukan untuk meningkatkan ketersediaan tanah agar tidak ditahan oleh para spekulan tanah. Spekulan yang tidak menaati aturan akan diberi sanksi.

Permasalahan mendesak lainnya yang terjadi di Indonesia terutama di kota besar adalah distribusi lahan yang tidak merata. Adalah suatu problematika klasik ketika kita berkunjung ke suatu hotel mewah berbintang, permukiman perumahan mewah maupun pusat perbelanjaan mewah yang dikelilingi 
dengan perumahan kumuh. Tingkat kualitas pemukiman bagi masyarakat miskin sangatlah rendah. Akibat lebih lanjut yang dapat ditimbulkan adalah munculnya kesenjangan sosial antara masyarakat yang memiliki uang dan masyarakat yang tidak memiliki uang.

Keadilan sosial bagi seluruh rakyat Indonesia seperti yang dicita-citakan oleh bangsa Indonesia dengan konsep Pancasila tidak akan pernah terwujud bila tidak dimulai dengan keadilan dalam distribusi aset berupa tanah. Penguasaan berlebih oleh individu atau kelompok seharusnya dibatasi, baik dengan peraturan langsung maupun dengan pajak.

Adapun tujuan dari pembentukan land banking, sebaiknya meliputi:27

1. Menjamin tujuan dan kepentingan yang dirumuskan dalam UUD NRI Tahun 45 Pasal 33 beserta amandemennya.

2. Mendukung pembangunan nasional yang berkelanjutan, adil dan merata bagi kepentingan rakyat banyak.

3. Mampu mengendalikan perkembangan wilayah secara efisien dan efektif.

4. Mampu mengendalikan penguasaan dan pemanfaatan tanah secara adil dan wajar dalam melaksanakan pembangunan.

\section{Dasar pembentukan bank tanah di Indonesia}

Dalam konteks Indonesia, kelembagaan bank tanah wajib disandarkan pada Pasal 33 ayat (3) UUD NRI Tahuh 1945 dan UUPA
Tahun 1960. Penyelenggaraan bank tanah harus berbentuk badan hukum publik, baik sebagai unit dan departemen yang sudah ada maupun institusi BUMN. Tidak cukup sampai disitu, Bank tanah memiliki tanggung jawab dan peranan yang sangat besar dan menyangkut kepentingan masyarakat banyak oleh karena itu haruslah dilakukan pengawasan dalam pelaksanaannya.

\section{Model perbandingan bank tanah di negara lain}

Konsep Bank Tanah telah banyak digunakan oleh negara-negara lain sebagai salah satu mekanisme untuk menjamin ketersediaan tanah bagi pembangunan, diantara negara-negara itu adalah Belanda, Filipina, Colombo dan Korea Selatan berikut adalah tinjauan penyelenggaraan bank tanah di negara-negara tersebut. ${ }^{28}$ Tinjauan penyediaan tanah di Belanda adalah praktik konsolidasi tanah dan land readjustment dilakukan bersama-sama dengan praktik instrumen bank tanah. Praktik Bank Tanah dibutuhkan dalam pelaksanaan Konsolidasi Tanah guna mempercepat pelaksanaan dan mempermudah proses akuisisi tanah. Lembaga yang berwenang bersifat ad hoc dan merupakan dewan nasional yang terdiri dari beberapa kementerian atau lembaga yang menjalankan tupoksi masing-masing dalam satu rencana pembangunan kawasan yang disepakati bersama, Kelembagaan ini 
bersifat non profit dan tidak ditujukan untuk mencari keuntungan. Peruntukan penggunaan adalahnpeningkatan kinerja lahan pertanian, restorasi sungai, dan penggantian lingkungan yang rusak (penghijauan), hambatan yang terjadi adalah terjadinya inkonsistensi untuk lembaga non profit karena seringkali terjadi rencana peruntukan yang dipergunakan untuk restorasi sungai dan penghijaun malah beralih mengakomodir kepentingan komersial.

Negara kedua dan berlokasi di Asia Tenggara yang menganut sistem bank tanah adalah Filipina. Pelaksanaan di Filipina agak sedikit berbeda, lembaga yang berwenang melaksanakan Bank Tanah adalah BUMN dengan 2 operasi yakni Bank Tanah dan Bank Tanah Komersial. Tujuannya ditujukan untuk non profit (Bank Tanah) dan yang bertujuan mencari keuntungan (Bank Komersial Konvensional). Keuntungan yang didapatkan digunakan untuk membiayai operasional Bank Tanah yang Non Profit. Peruntukan pelaksanaan Bank Tanah adalah reforma agraria, peningkatan kinerja pertanian, dan melaksanakan fungsi Bank Konvensional. Hambatan yang terjadi pada tahap pelaksanaan adalah skandal penipuan (mark up harga), aset yang dipinjamkan ke petani dijual, namun tercatat bahwa skandal tersebut dapat terselesaikan dalam satu tahun dengan pencabutan kewenangan kementerian agraria dalam melakukan pembelian lahan dan dialihkan ke BUMN.

\section{Bentuk kelembagaan bank tanah}

Kelembagaan bank tanah dapat mengambil beberapa bentuk, yaitu (1) bank tanah BUMN, (2) bank tanah Badan Layanan Umum (3) Bank tanah yang beriringan dengan Bank Komersial Konvensional. Dari tabel didapatkan bentuk yang paling tepat adalah berbentuk BLU di bawah BPN. Pengawan dilakukan oleh lembaga pemerintah lainnya seperti Kementerian PPN, Kemenpera, dan KemenPU.

Seperti yang telah diutarakan sebelumnya kendala utama dalam pembangunan infrastruktur adalah melambungnya harga lahan, kenaikan tanah setiap tahun adalah sebesar 20 persen. Harga tinggi bahkan melebihi prakiraan harga dari appraisal dari masyarakat pemilik tanah seakan menjadi permasalahan yang tak akan berujung. Penyebab keterbatasan lahan tersebut adalah ketersediaan tanah, yakni tidak bisa mendapatkan akses tanah ataupun bisa mendapatkan akses tanah namun harga yang dipatok sudah terlalu tinggi sehingga melampaui perencanaan keuangan yang dibuat oleh negara.

Solusi yang dapat digunakan dalam mengatasi permasalahan pembebasan lahan adalah mekanisme Bank Tanah tersebut, lembaga yang tepat digunakan dalam mekanisme pelaksanaan adalah berbentuk Badan Layanan Umum. Bank Tanah akan memiliki fungsi sebagai lembaga yang akan membeli tanah dari masyarakat sebelum pembangunan dimulai. Pada tahap perencanaan penentuan daerah yang akan dibangun, BLU Bank Tanah sudah mulai 
bergerak untuk membeli tanah. Skema pembebasan tanah saat ini dilakukan setelah tahap lelang selesai sehingga menyebabkan harga tanah melonjak tinggi.

Instansi yang berwenang mengadakan pengadaan tanah adalah Lembaga Negara, Kementerian, Lembaga Pemerintah Non Kementerian, Pemerintah Provinsi, Pemerintah Kabupaten/ Kota, Badan Hukum Milik Negara (penugasan Khusus), Badan Usaha Milik Negara (penugasan khusus).

Skema kelembagaan penyediaan tanah apakah yang tepat digunakan di Indonesia haruslah memenuhi kriteria sebagai berikut, sesuai dengan Undang-Undang Dasar Negara Republik Indonesia Tahun 1945 Pasal 33, Berorientasi pelayanan masyarakat dan tidak ditujukan untuk mencari keuntungan, mempunyai kompetensi dalam pertanahan (pembuatan regulasi, sistem informasi dan SDM), pengaturan pembiayaan yang efektif dan efisien dalam pelaksanaan kebijakan.

Bentuk kelembagaan dapatlah berupa Badan Layanan Umum (untuk selanjutnya disebut BLU), BUMN ataupun Bank Komersial Konvensional. Berikut merupakan komparasi kelembagaan lembaga penyediaan tanah yang lebih sesuai di Indonesia. Berdasarkan PP No. 23 Tahun 2005 tentang Pengelolaan Keuangan BLU Pasal 2 dan Pasal 3, kinerja BLU dinilai berdasarkan pelayanan dan bukan merupakan subjek pajak sedangkan BUMN sesuai dengan ketentuan dalam Pasal 2 Undang-undang No. 19 tahun 2003 tentang Badan Usaha Milik Negara kinerja BUMN dinilai berdasarkan pelayanan dan pendapatan profit dan perusahaan merupakan subjek pajak pendapatan.

Bagaimana dengan kedudukan Bank Komersial sebagai lembaga yang berwenang dalam penyediaan tanah, berdasarkan Peraturan Bank Indonesia No. 14/26/PBI/2012 tentang kegiatan usaha dan modal Inti Bank, maka Bank tidak diperbolehkan melakukan jual beli aset dan menyimpan aset yang besar karena akan mengganggu likuiditas bank tersebut. Hal ini dapat menimbulkan dampak sistemik bagi kesehatan bank tersebut. Dengan demikian, Bank Konvensional tidak diperkenankan memiliki kewenangan sebagai lembaga penyedia Bank tanah.

Dengan demikian Badan Layanan Umum penyediaan tanah di bawah Kementerian Agraria dan Tata Ruang (ATR) dinilai paling tepat dibandingkan bentuk lainnya dengan alasan sebagai berikut:

1. Dapat menjaga agar BLU tetap merupakan lembaga non profit, sejalan dengan amanat Undang-Undang Dasar Negara Republik Indonesia Tahun 1945 Pasal 33 dan UUPA yang menjadi landasan kerja BPN agar sumber daya tanah dipergunakan sebesar-besarnya untuk kemakmuran rakyat.

2. BPN bukan merupakan institut pengguna lahan sehingga tidak memiliki konflik kepentingan di dalamnya.

3. Jangkauan wilayah kerja BPN melingkupi kabupaten dan kota melalui kantor wilayah di Provinsi dan Kantor Pertanahan di Kabupaten dan Kota 
4. Memiliki pengalaman dalam administrasi pertanahan. Sistem informasi pertanahan, penilaian tanah, akuisisi tanah.

\section{Simpulan}

Simpulan yang dapat diambil adalahUrgensi Pembentukan kelembagaan Bank Tanah adalah sebagai alternatif mekanisme penyediaan tanah di samping yang telah diatur oleh Undang-undang No. 2 Tahun 2012. Keadaan yang terjadi saat ini adalah terhambatnya pembangunan akibat lahan yang belum tersedia terutama di daerah perkotaan, pembebasan lahan yang berlarut dan pergeseran makna tanah.Keberadaan Bank Tanah dapat menjalankan apa yang telah diamanatkan oleh UUD NRI Tahun 1945 dan UUPA 1960 tersebut. Bank Tanah dapat menjawab berbagai persoalan mendesak yang selama ini kerap membayangi pembangunan infrastruktur seperti keterbatasan stok tanah yang dapat digunakan untuk pembangunan, melakukan penghematan terhadap dana APBN dan APBD, mengurangi konflik yang kerap terjadi dalam pembebasan tanah dan mengurangi dampak buruk dari praktik spekulasi harga tanah yang kerap dilakukan oleh mafia tanah. Dalam operasionalisasinya, bank tanah haruslah menjadi instrumen pelaksana UU No. 2 Tahun 2012 tentang Pengadaan Tanah bagi Kepentingan Umum dan hanya dikhususkan untuk pengadaan tanah bagi Kepentingan Umum.

Model Kelembagaan Bank Tanah yang tepat adalah berbentuk kelembagaan BLU dinilai paling tepat untuk Bank Tanah sebab sesuai dengan amanat undang-undang. Dengan demikian Badan Layanan Umum penyediaan tanah di bawah Kementerian Agraria dan Tata Ruang (ATR) dinilai paling tepat dibandingkan bentuk lainnya dengan alasan sebagai berikut: Dapat menjaga agar BLU tetap merupakan lembaga non profit, sejalan dengan amanat Undang-Undang Dasar Negara Republik Indonesia Tahun 1945 Pasal 33 dan UUPA, BPN bukan merupakan institut pengguna lahan, Jangkauan wilayah kerja BPN yang luas, Memiliki pengalaman dalam administrasi pertanahan. Sistem informasi pertanahan, penilaian tanah, akuisisi tanah. Skema kelembagaan penyediaan tanah apakah yang tepat digunakan di Indonesia haruslah memenuhi kriteria sebagai berikut, sesuai dengan Undang-Undang Dasar Negara Republik Indonesia Tahun 1945 Pasal 33. Bentuk kelembagaan dapatlah berupa Badan Layanan Umum, BUMN ataupun Bank Komersial Konvensional. 


\section{DAFTAR PUSTAKA}

\section{Buku}

Hamidjoyo, Noto dalam Adrian Sutedi. Implementasi Prinsip Kepentingan Umum dalam Pengadaan Tanah Untuk Pembangunan. Jakarta: Sinar Grafika, 2007.

Harsono, Boedi. Hukum Agraria Indonesia (Sejarah Pembentukan UndangUndang Pokok Agraria, Isi dan Pelaksanaannya). Jakarta: Djambatan, 2003.

Limbong, Bernhard. Bank Tanah. Jakarta: Margaretha Pustaka, 2013.

Marzuki, Peter Mahmud. Penelitian Hukum. Jakarta: Prenada Media, 2005.

Mertokusumo, Sudikno. Teori Hukum.

Yogyakarta: Atmajaya, 2012.

Nasution, Bahder Johan. Metode Penelitian Ilmu Hukum. Bandung: Mandar Maju, 2008.

Rosadi, Otong. Pertambangan dan Kehutanan dalam PerspektifCita Hukum Pancasila Dialektika Hukum dan Keadilan Sosial. Yogyakarta: Thafa Media, 2012.

\section{Skripsi, Tesis}

Alexander, Frank S. Land Banking As Metropolitan Policy. Brookings Institution Metropolitan Policy Program. 2008.

BAPPENAS. Ringkasan Hasil-Hasil Kajian Komponen 1 Land Management and Policy Development Project Tahun
2007-2008 [Summary of the Results of the Study Component 1 of LMPDP 2007-2008]. Jakarta, 2009.

Habib, Tatit Januar. "Pelaksanaan Penetaan Ganti Kerugian dan Bentuk Pengawasan Panitia Pengadaan Tanah pada Proyek Pembanguan Terminal Bumiayu". Thesis Ilmu Hukum, Program Pasca Sarjana Magister Ilmu Hukum Universitas Diponegoro. Semarang: Universitas Diponegoro, 2007. Tidak Dipublikasikan.

Miya Irawati, Urban Land Provisioning for Development of Public Interest, Directorat of Land Spatial Planning and Land Affair. 2014.

\section{Jurnal}

Hadimoeljono, Basoeki. "Mencari Kelembagaan Pengendalian Pemanfaatan Ruang yang Efektif'. Jurnal Direktorat Tata Ruang dan Pertanahan BAPPENAS Vol. II, (Juni 2013): 23.

Noor, Raffli. "Manajemen Bank Tanah". Jurnal Direktorat dan Tata Ruang BAPPENAS, Vol. I, (Maret 2014): 19.

T. Van Dijk and D Kopeva. "Land Banking And Central Europe: Future Relevance Current Initiatives, Western European Past Experience". Journal Land Use Policy Vol. 30, (April 2003): 150. 


\section{Naskah Internet}

Badan Perencanaan Pembangunan Nasional Republik Indonesia (Bappenas). International Experiences in Land Banking and Related Landa Tools. Email dari Narasumber dari Bappenas. Diakses 13 Pebruari 2015.

Land Bank of Taiwan. "About Us". https:// www.landbank.com/about. Diakses 10 Pebruari 2015.

Tambak, Ruslan. "Akhirnya Pemerintah Wacanakan Bank Tanah". http://www. rmol.co/read/2015/02/13/191351/
Akhirnya-Pemerintah-WacanakanBank-Tanah-. Diakses 13 Pebruari 2015.

Land Bank of Philippines. "About History". https://www.landbank.com/history. Diakses 20 September 2015.

\section{Peraturan Perundang-undangan}

Undang-undang Nomor 5 Tahun 1960 tentang Ketentuan Pokok Dasar-Dasar Agraria.

Undang-undang Republik Indonesia Nomor 12 Tahun 2011 tentang Pembentukan Peraturan Perundang-undangan. 